\title{
Granular Cell Tumor of the Esophagus: A Patient Treated by Endoscopic Mucosal Resection with Long Term Follow-Up
}

\author{
Siu-Kee Leung ${ }^{1 *}$, Shing-Hoi Fung ${ }^{2}$, Siu-Chuen Chiu ${ }^{3}$ \\ ${ }^{1}$ Department of Surgery, Tuen Mun Hospital, Hong Kong, China; ${ }^{2}$ Department of Pathology, Pamela Youde Nethersole Eastern Hos- \\ pital, Hong Kong, China; ${ }^{3}$ Department of Pathology, Tuen Mun Hospital, Hong Kong, China. \\ Email: *drleungsk@hotmail.com
}

Received April 28 ${ }^{\text {th }}, 2012$; May $10^{\text {th }}, 2013$; accepted June $2^{\text {nd }}, 2013$

Copyright (C) 2013 Siu-Kee Leung et al. This is an open access article distributed under the Creative Commons Attribution License, which permits unrestricted use, distribution, and reproduction in any medium, provided the original work is properly cited.

\begin{abstract}
Granular cell tumors (GCTs) of the esophagus are uncommon. We report a case of granular cell tumor of esophagus treated by endoscopic mucosal resection (EMR) with long term follow-up.
\end{abstract}

Keywords: Granular Cell Tumor; Esophagus; Endoscopic Mucosal Resection; Long Term Follow-Up

\section{Introduction}

Granular cell tumors (GCTs) of the esophagus are uncommon. They are usually small and well circumscribed. Evaluation by endoscopic ultrasound (EUS) is useful. If the lesion is limited to the submucosa, endoscopic removal is feasible. We report a case treated by endoscopic mucosal resection (EMR) with long-term follow-up.

\section{Case Report}

A 40-year-old man presented with mild epigastric pain for one year. He was a heavy smoker with chronic obstructive pulmonary disease. There was no symptom of gastroesophageal reflux. He could tolerate full solid diet and there was no weight loss. Physical examination was unremarkable.

Upper gastrointestinal endoscopy revealed a nodular, yellowish-white lesion over mucosa of esophagus, at 35 $\mathrm{cm}$ from incisor (Figure 1). EUS using a $20 \mathrm{MHz}$ probe was performed. The tumor was $1 \mathrm{~cm}$ in maximal diameter. It was hyperechoeic compared with muscularis propria, and confined to the submucosa (Figure 2). Endoscopic mucosal resection (EMR) was performed, using submucosal injection of normal saline and loop snaring technique.

Histological examination showed sheets of spindled and polygonal cells with small bland regular nuclei and

"Corresponding author.

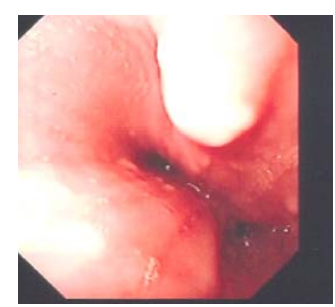

Figure 1. Endoscopic view of granular cell tumor of esophagus.

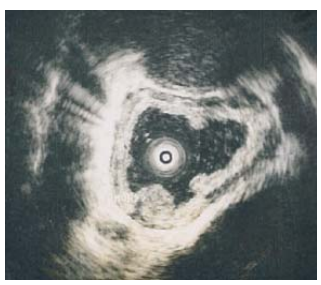

Figure 2. Endoscopic ultrasound view.

abundant palely eosinophilic granular cytoplasm.

Low power view with Hematoxylin and Eosin (H \& E) stain (Figure 3) showed a small oval, well-demarcated submucosal nodule, composed of sheets of spindled and polygonal cells. Cytologically (Figure 4), they showed small round or slightly irregular nuclei and abundant palely eosinophic granular cytoplasm. Mitosis was not seen and pleomorphism was minimal. Immunohisto chemical stain with S100 showed strong positivity (Figure $5)$. 


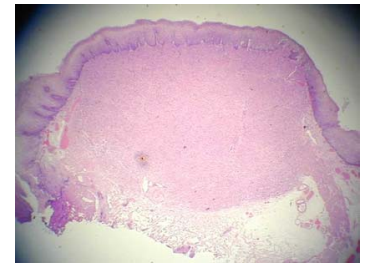

Figure 3. Low power, Hematoxylin and Eosin stain (H \& E stain).

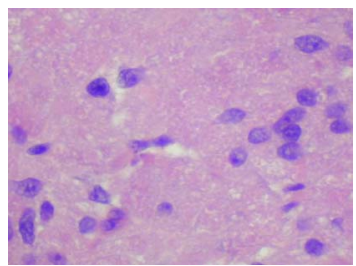

Figure 4. High power view, H \& E stain.

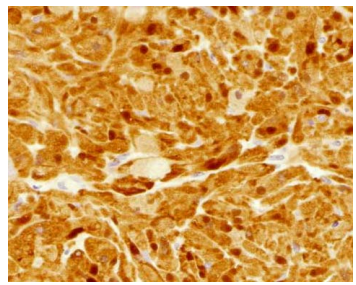

Figure 5. S100 stain.

Follow-up endoscopy was performed at 1,3 months and then yearly for 4 years. The findings were normal. The patient remained asymptomatic for 10 years after EMR.

\section{Discussion}

First described by Abrikossoff in 1931, GCTs of the esophagus are uncommon tumors. They are stromal lesions originating from the Schwann cells of the submucosal neuronal plexus [1-3]. They constitute the second largest group of non-epithelial tumors in the esophagus after leiomyoma [3,4].

The lesion is commonly located in the distal one third of the esophagus. GCTs are generally considered benign, although a few malignant cases have been reported [3]. They may be multiple and synchronous [2]

The history of determining the histogenesis of GCTs is interesting. Initially they were called granular cell myoblastomas. However, histochemical studies show that they are intensely stained with antiserum to S-100 protein, which is a marker of Schwann cells [1].
Endoscopically, GCTs appear as small, yellow mucosa lesions.

In endoscopic ultrasonography, GCTs arise from the submucosal layer. Compared with esophageal leiomyoma, they are more hyperechoeic. The use of high frequency ultrasound probes is useful to differentiate the two [4,5].

When EUS shows that there is no evidence of involvement of muscularis propria (MP), endoscopic mucosal resection (EMR) is a feasible treatment modality $[5,6]$.

When the lesion is large or when there is invasion of MP, surgical treatment may become necessary. However, consensus is lacking on the treatment and follow-up of this tumor.

The reported case is a patient with GCT treated by EMR. He remained well for 10 years after the procedure.

\section{REFERENCES}

[1] K. Stefansson and R. L. Wollmann, "S-100 Protein in Granular Cell Tumors (Granular Cell Myoblastomas)," Cancer, Vol. 49, No. 9, 1982, pp. 1834-1838. doi:10.1002/1097-0142(19820501)49:9<1834::AID-CNC R2820490916>3.0.CO;2-G

[2] J. R. Goldblum, T. W. Rice, G. Zuccaro and J. E. Richter, "Granular Cell Tumors of the Esophagus: A Clinical and Pathologic Study of 13 Cases," Annals of Thoracic Surgery, Vol. 62, No. 3, 1996, pp. 860-865. doi:10.1016/S0003-4975(96)00443-2

[3] L. De Rezende, A. J. Lucendo and H. Alvarez-Arguelles, "Granular Cell Tumors of the Esophagus: Report of Five Cases and Review of Diagnostic and Therapeutic Techniques,” Diseases of the Esophagus, Vol. 20, No. 5, 2007, pp. 436-443. doi:10.1111/j.1442-2050.2007.00692.x

[4] D. U. Kim, G. H. Kim, D. Y. Ryu, D. G. Lee, J. H. Cheong, B. E. Lee, G. A. Song, Y. Park do, N. R. Shin, I. H. and M. Kida, "Endosonographic Features of Esophageal Granular Cell Tumors Using a High-Frequency Catheter Probe," Scandinavian Journal of Gastroenterology, Vol. 46, No. 2, 2011, pp. 142-147.

[5] M. Esaki, K. Aoyagi, K. Hizawa, S. Nakamura, K. Hirakawa, H. Koga, T. Yao and M. Fujishima, "Multiple Granular Cell Tumors of the Esophagus Removed Endoscopically: A Case Report,” Gastrointestinal Endoscopy, Vol. 48, No. 5, 1998, pp. 536-539. doi:10.1016/S0016-5107(98)70102-6

[6] L. Palazzo, B. Landi, C. Cellier, G. Roseau, S. Chaussade, D. Couturier and J. Barbier, "Endosonographic Features of Esophageal Granular Cell Tumors,” Endscopy, Vol. 29, No. 9, 1997, pp. 850-853. doi:10.1055/s-2007-1004320 